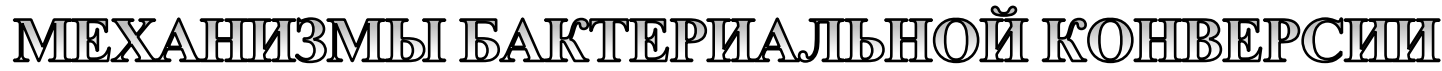

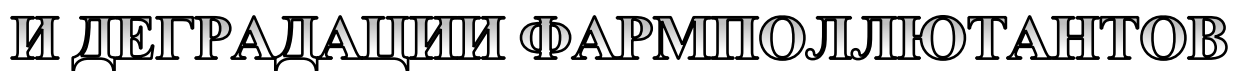

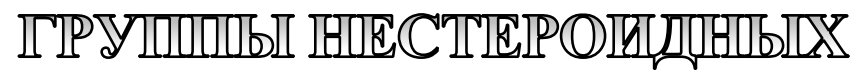

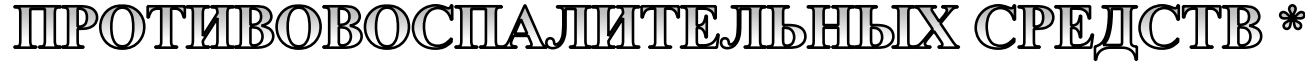

И.Б. Ившина, Пермский федеральный исследовательский центр УрО РАН; Пермский государственный национальный исследовательский университет Е.А. Тюмина, Пермский федеральный исследовательский центр УрО РАН; Пермский государственный национальный исследовательский университет Г.А. Бажутин, Пермская государственная фармачевтическая академия

А.А. Селянинов, Пермский национальный исследовательский политехнический университет Е.В. Вихарева, Пермская государственная фармачевтическая академия

В последние годы наблюдается устойчивое повышение фундаментального интереса к исследованию степени биодоступности и токсического воздействия фармацевтических поллютантов на природные микроорганизмы, играющие роль системы первичного реагирования на ксенобиотическую нагрузку окружающей среды. На основе биоресурсов Региональной профилированной коллекции алканотрофрных микроорганизмов (официальный акроним коллекции ИЭГМ, реестровый номер Уникальной научной установки 73559 , номер 285 во Всемирной федерации коллекций культур, http://www.iegmcol.ru) впервые установлена способность актинобактерий рода Rhodococcus к деструкции сложных соединений ароматического ряда, составляющих основу широко применяемых в медицинской практике нестероидных противовоспалительных средств (НПВС). Отобраны штаммы - активные биодеструкторы диклофенака натрия $и$ ибупрофрена, наиболее часто детектируемых в окружающей природной среде НПВС и представляющих наибольший потенциальный риск для гидробиоты и человека. Изучены кинетика и основные закономерности процесса биодеградации фрармполлютантов. Осуществлена идентификация продуктов бактериального разложения экотоксикантов, охарактеризованы пути их биодеструкции, описаны математические модели процесса полной бактериальной деградации фармполлютантов в высокой концентрации. Впервые получены данные, подтверждающие разрыв связи C-N и раскрытие ароматического цикла в молекуле диклофенака, сопровождающиеся образованием неопасных для живых организмов метаболитов. Оценена потенциальная биоактивность отдельных продуктов метаболизации диклофенака. Выявлены наиболее

\footnotetext{
* Исследования поддержаны грантом Российского фонда фундаментальных исследований и Министерства образования и науки Пермского края (№ 17-44-590567 «Механизмы бактериальной конверсии и деградации фармполлютантов группы нестероидных противовоспалительных средств»).
} 
типичные реакции родококков на воздействие НПВС: изменение дзетапотенциала, морфометрических параметров и степени гидрофобности бактериальных клеток, повышение содержания суммарных клеточных липидов и образование бактериальных ассоциатов.

Результаты проведенных исследований рассматриваются в качестве механизмов адаптации родококков и повышения их устойчивости к токсическому воздействию фрармполлютантов. Полученные фрундаментальные данные дают представление об экологической роли актинобактерий рода Rhodococcus в детоксикации фармполлютантов и создают предпосылки для реализации технических решений процессов доочистки сточных вод фрармацевтических предприятий и обезвреживания опасных фрармотходов.

Ключевые слова: биодеструкиия, актинобактерии, Rhodococcus, фармполлютанты, НПВС, диклофенак, ибупрофен.

\section{Введение}

На фоне крайне напряженной экологической ситуации неуклонно возрастает риск медикаментозного загрязнения окружающей природной среды. Серьезная озабоченность присутствием фармацевтических поллютантов в открытых экосистемах появилась сравнительно недавно. Только в начале 2000-х годов лекарственное загрязнение среды начали рассматривать как новую экологическую проблему, несущую растущую реальную угрозу для человека и всей биоты в глобальном масштабе.

Сегодня практически неизвестна «экологическая судьба» фармпрепаратов и их метаболитов в окружающей среде. Если вопросы воздействия их на человека и животных интенсивно изучаются, появились работы по влиянию тотально применяемых антипиритических и анальгетических агентов на растения, то исследования в отношении природных микроорганизмов, которым при контакте с данными ксенобиотиками приходится решать проблему их детоксикации, только начинают разворачиваться.

Среди микроорганизмов, участвующих в процессах самоочищения природных экосистем, важную экологическую роль в детоксикации и деконтаминации почв и воды могут играть актинобактерии - устойчивые обитатели загрязненных почв, водоемов, активного ила, сточных вод, обладающие высокой активностью оксидоредуктаз, богатыми адаптивными возможностями в отношении различных токсиче- ских соединений, а также высоким потенциалом для биоремедиации загрязненных объектов $[1,2]$. Актуальность использования метаболического потенциала актинобактерий для биодеградации фармвеществ подтверждается все возрастающим числом исследований [3-5]. В настоящей работе интерес представлял анализ возможного участия их в качестве эффективных биоокислителей фармпрепаратов группы нестероидных противовоспалительных средств (НПВС), наиболее часто детектируемых в окружающей среде [6].

Одними из таких антропогенных микрозагрязнителей являются диклофенак натрия $\left(\mathrm{C}_{14} \mathrm{H}_{10} \mathrm{Cl}_{2} \mathrm{NNaO}_{2}\right.$, CAS 15307-86-5, 2-(2-[2',6'-дихлорфенил]-амино)-фенилуксусная кислота в виде натриевой соли) и ибупрофен $\left(\mathrm{C}_{13} \mathrm{H}_{18} \mathrm{O}_{2}\right.$; CAS 15687-27-1; (RS)-2-[4-(2-метилпропил)фенил] пропановая кислота) - широкодоступные и часто применяемые в мировой медицинской практике и ветеринарии НПВС. Количественные характеристики ежегодно потребляемых диклофенака и ибупрофена выражаются тысячами тонн [7]. Диапазон их фактических концентраций в грунтовых [8], поверхностных (в том числе морских) [9], сточных водах [10] и даже питьевых водах [11] по всему миру варьируется от $0,02 \mathrm{Hг/л}$ до 100 мг/л. Несмотря на преимущественно относительно низкий уровень присутствия фармполлютантов в природной среде, их постоянное пополнение может привести к 
высоким долговременным концентрациям и стимулировать отрицательное воздействие на человека и природу $[12,13]$.

Использование традиционных физикохимических технологий удаления фармацевтических загрязнителей из водных растворов экологически небезопасно, поскольку ограничено возможностью образования побочных продуктов деструкции фармполлютантов, и весьма неэкономично в связи с высокими эксплуатационными расходами и энергозатратами [14]. Приоритет по показателям эффективности, безопасности и экономичности признается за биотехнологическими способами конверсии этих экологических стрессоров. Однако работы по биоконверсии НПВС, особенно диклофенака, пока немногочисленны $[15,16]$.

Цель настоящего проекта - углубленное исследование механизмов разложения фармполлютантов группы НПВС актинобактериями, изучение специфических особенностей взаимодействия «фармполлютант - микроорганизм» и оценка эффективности запускаемых защитных реакций бактериальных клеток в ответ на воздействие фармполлютантов.

\section{Материалы и методы исследования}

В работе использовали 220 штаммов актинобактерий, принадлежащих к 14 родам и поддерживаемых в Региональной профилированной коллекции алканотрофных микроорганизмов (официальный акроним коллекции ИЭГМ, реестровый номер УНУ 73559, номер во Всемирной федерации коллекций культур 285 , http://www.iegmcol.ru). Исследование влияния НПВС на бактериальные культуры изучали путём определения минимальных подавляющих концентраций (МПК) методом серийных разведений. Процесс биодеструкции диклофенака (50 мкг/л и 50 мг/л) и ибупрофена (100 мг/л) проводили в минеральной среде RS [17] с использованием свободных актинобактериальных клеток. В качестве дополнительных источников углерода и энергии использовали D-глюкозу (5 г/л) или $н$-гексадекан $(0,1$ об.\%).
При исследовании живых клеток с помощью системы совмещенного сканирования, состоящей из конфокального лазерного сканирующего микроскопа (КЛСМ) Olympus FV 1000 (Olympus Corporation, Япония) и атомно-силового микроскопа (ACM) Asylum MFP-3D (Asylum Research, США), бактерии обрабатывали красителем $\quad$ LIVE/DEAD ${ }^{\circledR} \quad$ BacLight $^{\mathrm{TM}}$ Bacterial Viability Kit (Invitrogen, США).

Для определения внутриклеточной локализации окислительных ферментов, участвующих в превращениях исходных соединений, получали супернатанты с цитоплазматическими и мембранными, а также ресуспендированный соникат с неэкстрагируемыми ферментными комплексами. Влияние ингибиторов оксигеназ на деструктирующую активность родококков изучали с использованием ингибиторов цитохром Р450-зависимых монооксигеназ (1-аминобензотриазол, амиодарона гидрохлорид, имидазол, кетоконазол, проадифен), которые вносили в среду до конечной концентрации 5 мМ. Содержание глюкозы и хлоридов в среде культивирования бактерий, а также каталазную активность последних определяли нефелометрически с использованием спектрофотометра Lambda EZ201 (Perkin-Elmer, США). Измерение дзета-потенциала бактериальных клеток проводили с помощью анализатора ZetaSizer Nano ZS (Malvern Instruments, Великобритания). Степень гидрофобности родококков оценивали методом Salt Aggregation Test. Количество суммарных клеточных липидов определяли гравиметрически. Качественный и количественный анализ продуктов биотрансформации экотоксикантов осуществляли с помощью методов высокоэффективной жидкостной хроматографии, газовой хромато-массспектрометрии и ИК-спектроскопии. Изучение фитотоксичности диклофенака и его метаболитов проводили согласно методическим рекомендациям [18]. Для оценки экотоксичности и прогноза спектров биологической активности метаболитов использовали компьютерные программы ECOSAR (Ecological Structure Activity 
Relationships), доступную в программном пакете EPI Suite TM (The Estimation Programs Interface, EPA, США), и PASSOnline (Prediction of Activity Spectra for Substances, http://www.pharmaexpert.ru/ passonline/index.php) соответственно.

\section{Результаты: \\ Определение устойчивости актинобактерий к НПВС}

По нашим данным, использованные в работе штаммы актинобактерий обладали различной степенью устойчивости к исходным НПВС. Наиболее токсичным оказался диклофенак (МПК 50-200 мг/л), наименее токсичным - ибупрофен (МПК 125-1000 мг/л). Наиболее устойчивыми к диклофенаку оказались штаммы $R$. ruber ИЭГМ 231 и ИЭГМ 346, R. erythropolis ИЭГМ 213, R. rhodochrous ИЭГМ 647 (МПК 200 мГ/л), G. terrae ИЭГМ 148 (МПК 150 мг/л); к ибупрофену - Nocardioides jensenii ИЭГМ 821, $R$. cerastii ИЭГМ 1243, R. cercidiphylli ИЭГМ 1184, R. erythropolis ИЭГМ 501, R. ruber ИЭГМ 596 (МПК $\geq 1000$ мГ/л), преимущественно выделенные ранее из грунтовых, бытовых и промышленных вод (http://www.iegmcol.ru/strains/index/html).

В экспериментах по биодеструкции исходных соединений использовали репрезентативные штаммы активных биоокислителей $R$. cercidiphylli ИЭГМ 1184 и $R$. ruber
ИЭГМ 346. В данном сообщении представлены результаты, касающиеся преимущественно биодеструкции диклофенака, как наиболее часто обнаруживаемого в окружающей среде фармполлютанта, признанного Еврокомиссией веществом, представляющим наибольший риск для окружающей природной среды [6] и характеризующегося высокой устойчивостью к биоразложению, способностью к персистированию и экотоксичностью в отношении наземных и водных организмов $[7,12,13]$.

\section{Биодеструкция НПВС \\ с использованием целых клеток \\ R. cercidiphylli ИЭГМ 1184 и R. ruber ИЭГМ 346}

В экспериментах с использованием диклофенака в высокой концентрации (50 мг/л) при дополнительном внесении глюкозы $(0,5 \%)$ остаточное содержание экотоксиканта в постферментационной среде $R$. ruber ИЭГМ 346 на 60 сут оставалось еще примерно $50 \%$ (рис. $1, a$ ).

Средняя скорость биодеструкции диклофенака на протяжении эксперимента составляла 0,4 мг/сут Максимальные (0,7 мг/сут) показатели скорости биодеструкции наблюдались в первые 10 сут эксперимента. Максимальная удельная скорость деградации диклофенака (мг диклофенака/мг СВ/сут) составляла 0,02 сут $^{-1}$.

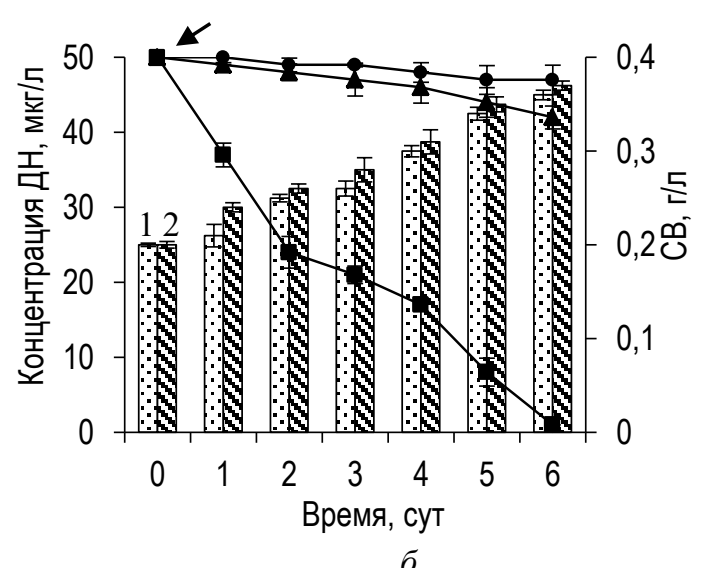

б

Рис. 1. Динамика биодеструкичи 50 мг/л (а) и 50 мкг/л (б) диклофенака (ДН) прединкубированными клетками R. ruber ИЭГМ 346 - в присутствии глюкозы: • - контроль абиотической деструкции; $\mathbf{\Delta}$ - контроль биосорбции; 1 - сухой вес (СВ) биомассы родококков в присутствии диклофенака и глюкозы; 2 - сухой вес биомассы родококков в присутствии глюкозы. Стрелками обозначено дробное внесение глюкозы 
В случае использования диклофенака в низкой (50 мкг/л) концентрации значительную убыль вещества регистрировали уже в первые двое суток эксперимента (рис. 1,б). При этом средняя скорость биоконверсии составляла 8,3 мкг/сут. На фоне достижения максимальной скорости (13 мкг/сут) биодеструкции диклофенака наблюдался постепенный стабильный прирост клеточной биомассы. На 5-е сут увеличение численности родококков сопровождалось значительной убылью диклофенака, полное разложение которого достигалось на 6-е сут эксперимента.

С использованием штамма R. cercidiphylli ИЭГМ 1184 в условиях предварительного выращивания клеток в присутствии $0,1 \% \quad \mu$-гексадекана полную деструкцию 100 мг/л ибупрофена наблюдали на 6 сут эксперимента (рис. 2).

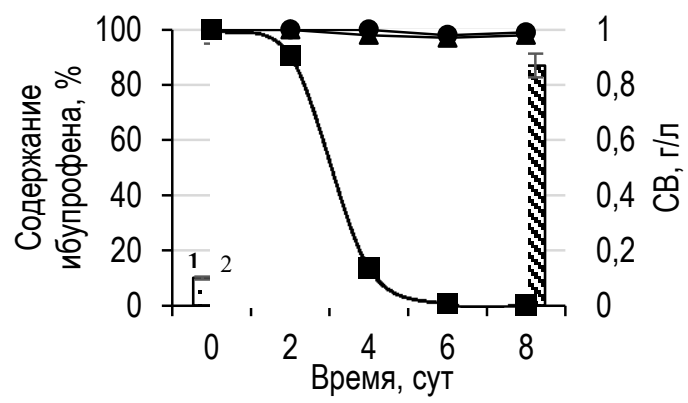

Pис. 2. Динамика биодеструкиии 100 мг/л ибупрофена клетками R. cercidiphylli ИЭГМ

1184: - - присутствии н-гексадекана,

- - контроль абиотической деструкции;

А - контроль биосорбции; 1 - сухой вес (CB) биомассы родококков в присутствии диклофенака и н-гексадекана; 2 - сухой вес биомассы родококков в присутствии н-гексадекана
Средняя скорость биоконверсии ибупрофена составляла 14,3 мг/сут, максимальные значения достигались на 4 сут и составляли 21,65 мг/сут. Максимальная удельная скорость биодеструкции ибупрофена составляла 0,031 сут $^{-1}$. В течение всего процесса биоконверсии ибупрофена отмечали прирост биомассы.

\section{Биодеструкция диклофенака с использованием клеточных фракций}

Известно, что в процессах бактериального окисления фармполлютантов участвуют ферменты, локализованные преимущественно в цитоплазме или связанные с клеточной мембраной [19]. В экспериментах с использованием клеточных фракций выявлено участие в процессе биодеструкции диклофенака (на разных его этапах) цитоплазматических и мембранносвязанных ферментов с образованием первичных гидроксипроизводных диклофенака (4'-гидроксии 5-гидроксидиклофенак) и фенилуксусной кислоты соответственно (табл. 1).

Известно, что в микробные реакции окисления НПВС вовлечены цитохром Р450-зависимые монооксигеназы [20]. По нашим данным, достоверное $(\mathrm{p}<0,05)$ ингибирование процесса биоразложения диклофенака отмечается в присутствии 1-аминобензотриазола и амиодарона (табл. 2). В присутствии других ингибиторов уровень биодеструкции экотоксиканта существенно не изменялся.

Таблий 1

Биодеструкция диклофренака с использованием отдельных фракций клеток $R$. ruber ИЭгМ 346

\begin{tabular}{|c|c|c|}
\hline Клеточная фракция & $\begin{array}{c}\text { Содержание } \\
\text { диклофенака, \% }\end{array}$ & Метаболиты, \% \\
\hline Цельноклеточный комплекс & $82,10 \pm 1,03$ & $\begin{array}{l}\text { 4'-гидроксидиклофенак } 3,30 \pm 0,47 \\
\text { 5-гидроксидиклофренак } 1,80 \pm 0,71\end{array}$ \\
\hline $\begin{array}{c}\text { Супернатант с цитоплазматическими } \\
\text { ферментами }\end{array}$ & $77,30 \pm 3,12$ & 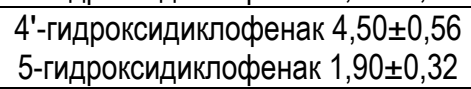 \\
\hline $\begin{array}{l}\text { Супернатант с Тритон-экстрагированными } \\
\text { мембранносвязанными ферментами }\end{array}$ & $85,30 \pm 2,74$ & Фенилуксусная кислота $3,10 \pm 0,71$ \\
\hline $\begin{array}{c}\text { Соникат клеток с неэкстрагируемыми } \\
\text { ферментами }\end{array}$ & 100,0 & - \\
\hline
\end{tabular}

Примечание. Приведены результаты после 10 сут инкубации. 
Таблииа 2

Влияние ингибиторов цитохром Р450-зависимых монооксигеназ на деструктирующую активность клеток $R$. ruber ИЭГМ 346 в отношении диклофенака

\begin{tabular}{|c|c|}
\hline Ингибитор & $\begin{array}{c}\text { Содержание } \\
\text { диклофенака, } \%\end{array}$ \\
\hline Без ингибитора & $83,00 \pm 1,24$ \\
\hline 1-аминобензотриазол & $\mathbf{9 5 , 6 0 \pm 2 , 3 6 *}$ \\
\hline Амиодарон & $\mathbf{9 8 , 2 0 \pm 4 , 7 9 ^ { * }}$ \\
\hline Кетоконазол & $86,60 \pm 3,01$ \\
\hline Имидазол & $79,30 \pm 2,95$ \\
\hline Проадифен & $85,40 \pm 4,21$ \\
\hline
\end{tabular}

Примечание. "Данные достоверно отличаются от контроля (без ингибитора). Приведены результаты на 10-е сут эксперимента.

\section{Математическое моделирование} процесса биодеструкции диклофенака

Сведения, полученные в экспериментах по биодеструкции диклофенака (см. рис. 1,a), использовали для математического прогноза продолжительности целевого процесса. Как видно из рис. 3, процесс биодеструкции диклофенака проходил по интенсивному пути, то есть максимальная скорость биодеструкции наблюдалась в течение первых суток эксперимента, что адекватно можно было отразить на кинетическом уравнении первого порядка:

$$
\mathrm{d} x / \mathrm{d} t=-\mathrm{k} x
$$

при концентрации вещества $x_{0}=100 \%$ в качестве начального условия и при

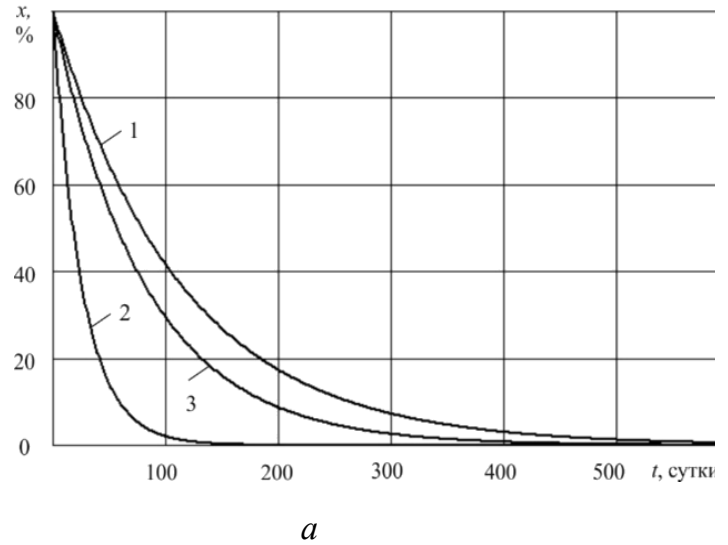

постоянной величине параметра скорости биодеструкции $k=$ const.

Для прогноза времени уменьшения в 100 раз 50 мг/л диклофенака с заданной вероятностью 95\% использовали верхнюю границу доверительного интервала изменения его концентрации с соответствующей вероятностью. Согласно методике [21], были найдены значения $k^{-}$и $k^{+}$, определяющие нижнюю 2 и верхнюю 1 границы доверительного интервала. Для логнормального закона распределения были получены значения $k^{-}=0,0390$ сут $^{-1}$ и $k^{+}=0,0088 \mathrm{cyт}^{-1}$, для нормального $k^{-}=0,0260$ сут $^{-1}$ и $k^{+}=0,0082$ сут $^{-1}$. Для установления времени уменьшения концентрации в определенное число раз на оси ординат откладывали соответствующее значение концентрации диклофенака $(\%)$ и по кривой 1 на рис. 3 определяли прогноз времени. Прогноз времени уменьшения концентрации диклофенака в процессе бактериальной деструкции в 100 раз с вероятностью 95\% с применением логнормального закона распределения параметра математической модели составлял 526 сут, с нормальным - 562 сут.

\section{Реакции бактериальных клеток на воздействие НПВС}

По нашим данным, наиболее типичной реакцией родококков в ответ на присутствие фармполлютантов являлось формирование в жидкой среде обособленных многоклеточных агрегатов разного раз-

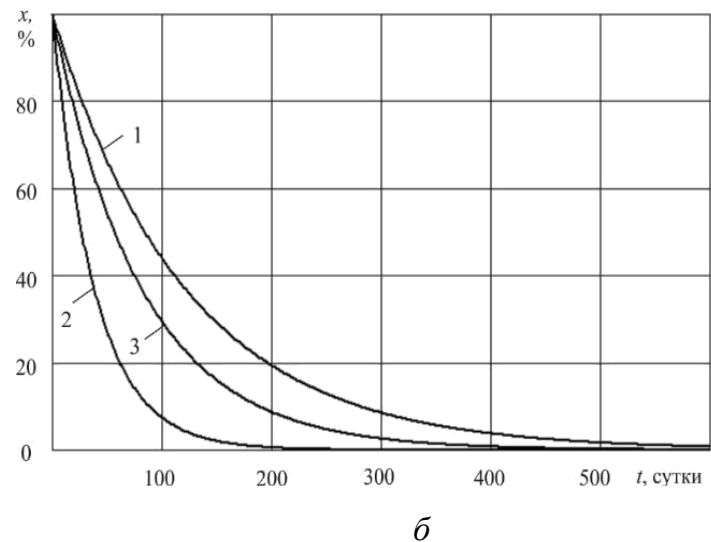

Рис. 3. Доверительный интервал для изменения концентрации диклофенака (50 мг/л) с вероятностью 95\% при логнормальном (а) и нормальном (б) законах распределения: 1 - верхняя граница; 2 - нижняя граница; 3 - выборочный аналог математического ожидания 
мера (10-70 мкм) неправильной формы (рис. 4,6, рис. $5,6,2$ ). Такая «кооперативная клеточная система», очевидно, обеспечивает согласованное функционирование многочисленных

ассоциированных клеток, позволяет популяции адаптироваться и расти в «жестких» условиях, при которых одиночные клетки не способны к размножению и биодеструкции экотоксикантов [22]. Наиболее выраженная объемная агрегация клеток отмечалась в присутствии высоких (50 мг/л) концентраций

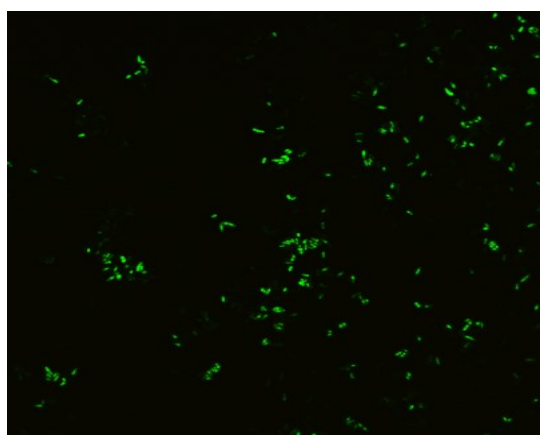

Puc. 4. КЛСМ-изображения клеток R. cercidiphylli ИЭГМ 1184, вырашенных в МПБ (a) и в присутствии ибупрофена (б)
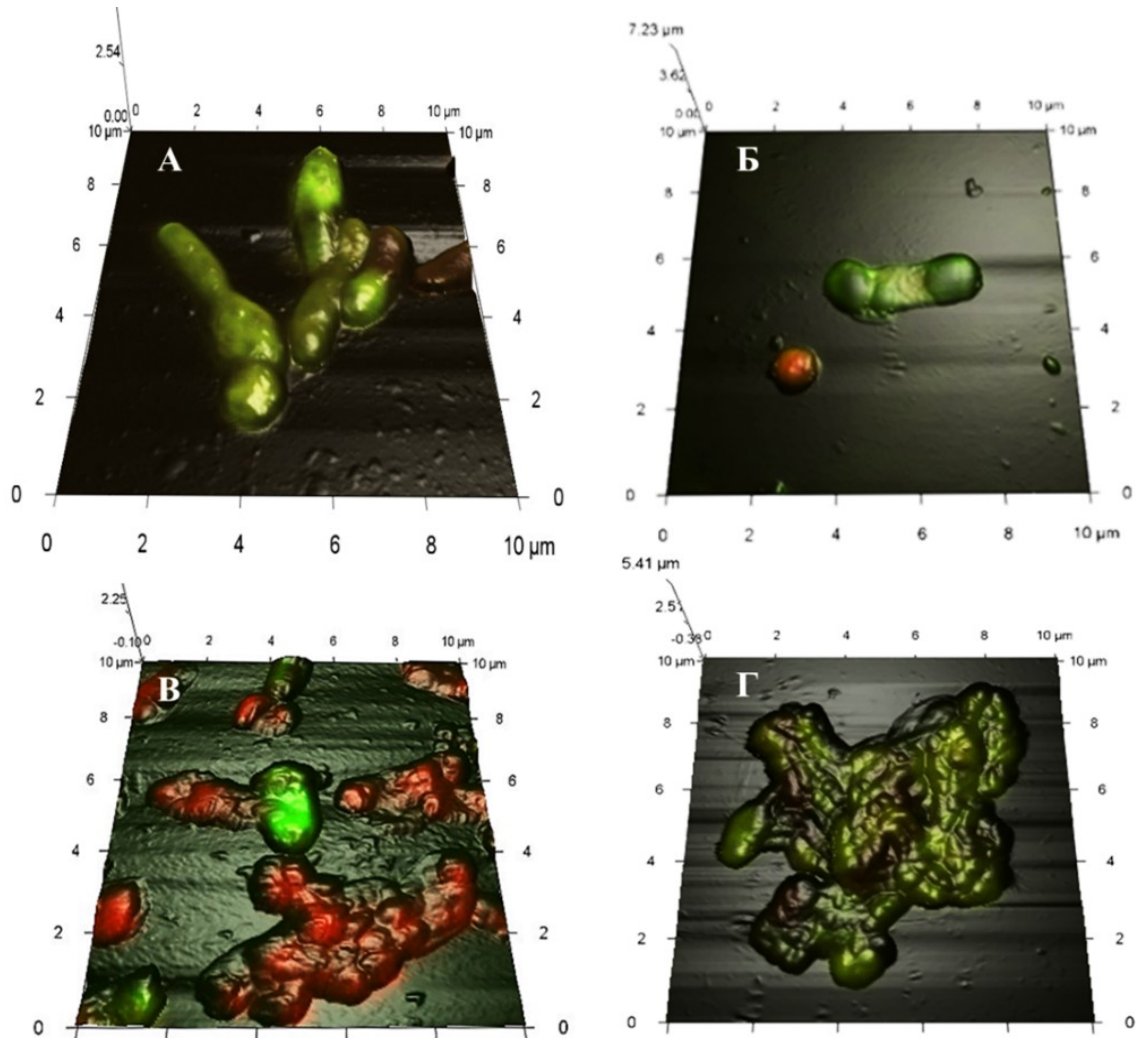

Pис. 5. Совмещенные 3D АСМ-КЛСМ-изображения R. ruber ИЭГМ 346. Клетки выращиивали в течение 10 сут в присутствии глюкозы (а); 50 мкг/л диклофенака и глюкозы (б, г); 50 мг/л диклофенака и глюкозы (в). Поврежденные клетки отмечены красным свечением

диклофенака на 10-е сут эксперимента (рис. 5,б). В этих условиях регистрировали максимальный уровень искажения морфологической структуры клеток: изменение формы и укрупнение средних размеров вегетативных клеток. У одиночных клеток нередко отмечалось повреждение целостности пептидогликанового слоя, сопровождающееся выходом компонентов цитоплазмы во внешнюю среду (рис. 6), и накопление в образце мертвых клеток.

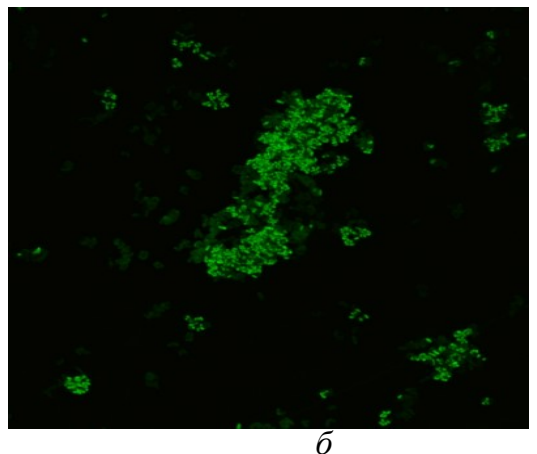
(a)

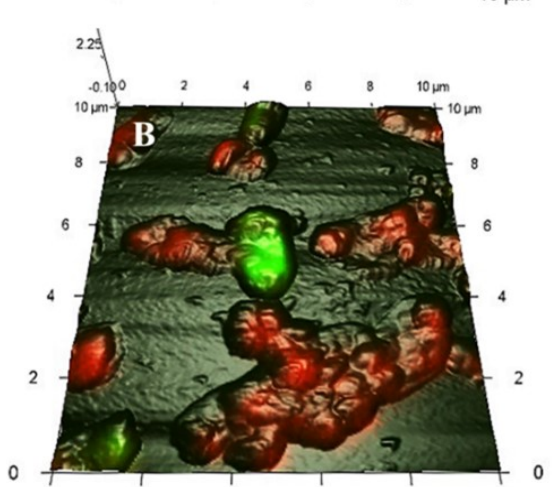



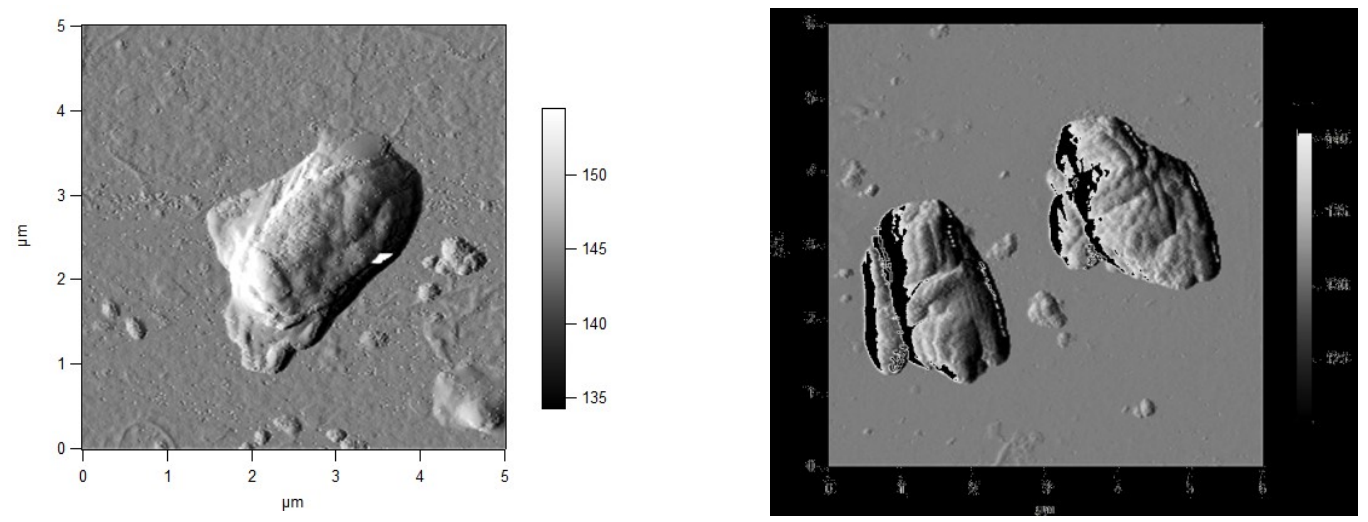

Puс. 6. АСМ-изображения клеток R. ruber ИЭГМ 346, выращзенных в течение 10 сут в присутствии 50 мг/л диклофенака. Стрелками указаны зоны повреждения клеток и изливания клеточного содержимого.

Таблица 3

Морфометрические параметры родококков в присутствии фармполлютантов

\begin{tabular}{|l|c|c|c|c|c|}
\hline \multicolumn{1}{|c|}{ Вариант } & Длина, мкм & Ширина, мкм & $\begin{array}{c}\text { Объем, } \\
\text { V, мкм }\end{array}$ & $\begin{array}{c}\text { Площадь, } \\
\text { S, мкм }{ }^{3}\end{array}$ & $S / V$, мкм $^{-1}$ \\
\hline \multicolumn{5}{|c|}{ R. cercidiphylli ИЭГМ 1184 } \\
\hline Контроль & $3,30 \pm 0,14$ & $1,00 \pm 0,27$ & $2,60 \pm 0,07$ & $6,80 \pm 0,17$ & $2,60 \pm 0,12$ \\
\hline Ибупрофен (100 мг/л) & $1,30 \pm 0,11$ & $1,10 \pm 0,06$ & $1,10 \pm 0,00$ & $3,70 \pm 0,02$ & $3,40 \pm 0,05$ \\
\hline \multicolumn{7}{|c|}{ R. ruber ИЭГМ 346 } \\
\hline Контроль & $3,00 \pm 0,02$ & $0,90 \pm 0,05$ & $1,90 \pm 0,03$ & $5,50 \pm 0,05$ & $2,90 \pm 0,02$ \\
\hline Диклофренак (50 мг/л) & $3,50 \pm 0,13$ & $1,10 \pm 0,02$ & $3,30 \pm 0,05$ & $7,90 \pm 0,10$ & $2,40 \pm 0,08$ \\
\hline Диклофренак (50 мкг/л) & $2,20 \pm 0,05$ & $0,90 \pm 0,01$ & $1,00 \pm 0,02$ & $3,60 \pm 0,03$ & $3,60 \pm 0,02$ \\
\hline
\end{tabular}

При мечан ие. Здесь и в табл. 4 клетки выращивали в течение 10 сут

Деструктивное воздействие диклофена- нака и 100 мг/л ибупрофена: относительная ка на морфологическом уровне для родококков проявлялось в достоверном $(\mathrm{p}<0,05)$ изменении относительной площади $(\mathrm{S} / \mathrm{V})$ бактериальных клеток (табл. 3). Уменьшение поверхности относительно объема клеток, по-видимому, играет важную роль в «противостоянии» бактерий токсическому воздействию фармполлютанта за счет уменьшения открытой поверхности клеток для контакта с экострессором [23]. Иная картина наблюдалась в присутствии низкой (50 мкг/л) концентрации диклофеплощадь контакта родококков с субстратами, напротив, увеличивалась для лучшего их поглощения и потребления.

Исследование

микрогеометрии поверхности живых бактериальных клеток выявило увеличение среднеквадратичной шероховатости и амплитуды микрорельефа в присутствии обоих субстратов (табл. 4). Однако изменения данного показателя были выражены в разной степени: в присутствии диклофенака увеличение шероховатости клеточных

Таблица 4

Изменение свойств клеточной поверхности родококков в присутствии фармполлютантов

\begin{tabular}{|l|c|c|}
\hline \multicolumn{1}{|c|}{ Условия культивирования } & $\begin{array}{c}\text { Среднеквадратичная } \\
\text { шероховатость, нм }\end{array}$ & $\begin{array}{c}\text { Электрокинетический потенциал, } \\
\text { мВ }\end{array}$ \\
\hline \multicolumn{3}{|c|}{ R. cercidiphylli ИЭГМ 1184 } \\
\hline Контроль & $163,96 \pm 5,20$ & $-17,10 \pm 1,30$ \\
\hline Ибупрофен (100 мг/л) & $465,28 \pm 16,26$ & $-25,40 \pm 0,80$ \\
\hline \multicolumn{3}{|c|}{ R. ruber ИЭГМ 346 } \\
\hline Контроль & $197,80 \pm 2,30$ & $-35,27 \pm 2,33$ \\
\hline Диклофенак (50 мг/л) & $216,10 \pm 5,51$ & $-31,32 \pm 0,83$ \\
\hline Диклофенак (50 мкг/л) & $249,60 \pm 6,64$ & $-32,17 \pm 1,05$ \\
\hline
\end{tabular}


поверхностей составляло 9-20\%, тогда как при наличии ибупрофена $-65 \%$.

Воздействие диклофенака и ибупрофена на родококки сопровождалось также изменением электрокинетических свойств поверхности клеток (табл. 4). В присутствии ибупрофена происходило увеличение «отрицательности» дзета-потенциала по сравнению с таковыми показателями контрольных образцов. Обратная тенденция наблюдалась в присутствии диклофенака в высокой (50 мг/л) концентрации: электрокинетический потенциал смещался к более положительным значениям, что свидетельствовало о катионной природе экотоксиканта (возможно, за счет присутствия в молекуле диклофенака катиона натрия и его взаимодействия с карбоксильными группами миколовых кислот клеточной стенки родококков) и электростатическом характере первоначального взаимодействия диклофенака с бактериальными клетками (рис. 7). Клетки, выращенные в присутствии низкой (50 мкг/л) концентрации диклофенака, достоверно не отличались по величине дзета-потенциала от клеток, выращенных при высокой (50 мг/л) концентрации экотоксиканта.

Сдвиг дзета-потенциала в сторону более нейтральных значений может приводить к дестабилизации и лизису клеток [24]. В нашем исследовании это подтверждено появлением значительного числа поврежденных или лизированных клеточных форм в первые 10 сут

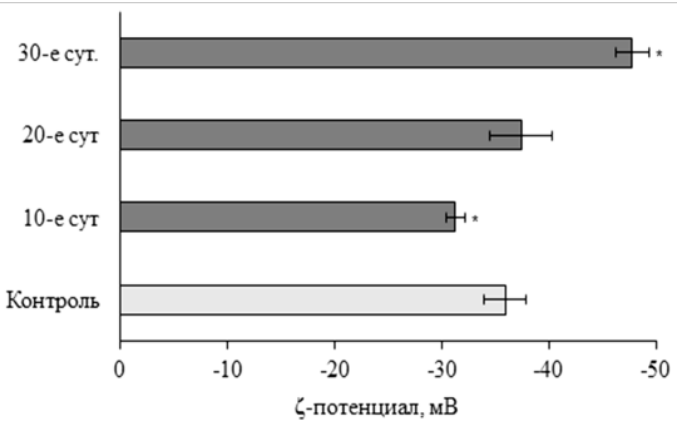

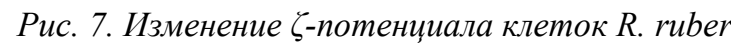
ИЭГМ 346. Клетки выращчивали в присутствии глюкозы (контроль $\square$ ); 50 мг/л диклофенака и глюкозы (口)

Примечание: *Данные достоверно $\quad(\mathrm{p}<0,05)$ отличаются от контрольных значений. эксперимента по биодеструкции диклофенака (см. рис. 6).

Другим подтверждением нахождения клеток в угнетенном состоянии в присутствии диклофенака служили показатели окислительного стресса, в частности выявленное изменение каталазной активности родококков (рис. 8).

На 10-е сут эксперимента регистрировали значительное увеличение (с 4,50 $\pm 0,15$ до $6,60 \pm 0,21$ мкМ/мин $\times$ ОП) каталазной активности родококков. Это, по-видимому, обусловлено тем, что в условиях окислительного стресса клетка расходует энергию на защитные ферментативные реакции, поскольку, как известно [25], неферментные антиоксидантные системы (гликоген, полисахариды, миколаты трегалозы) не осуществляют эффективную защиту от активных форм кислорода ввиду дестабилизации клеточных оболочек и нарушения целостности мембран (см. рис. 6).

С увеличением времени контактирования клеток с диклофенаком на 20-е, 30-е сутки наблюдалось смещение дзета-потенциала $(-37,47 \pm 2,33,-47,81 \pm 2,57$ мВ соответственно) в более отрицательную область, что коррелировало с установленным фактом увеличения содержания суммарных клеточных липидов (табл. 5), снижением каталазной активности, а также выраженным увеличением степени гидрофобности клеточной стенки родококков (рис. 9), сопровождающимся интенсивным формированием обособленных клеточных агрегатов. Выявленные закономерности свидетельствуют о том, что

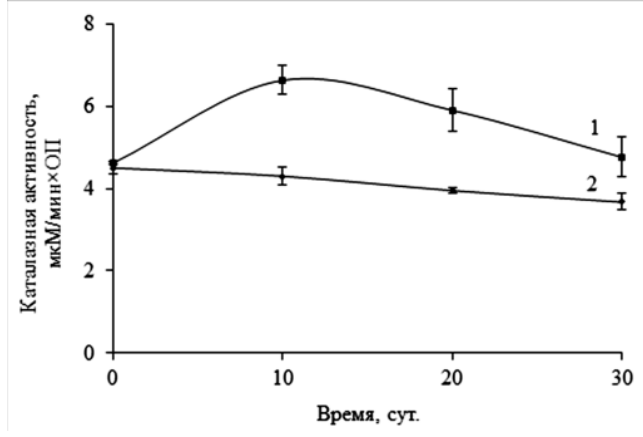

Рис. 8. Динамика каталазной активности клеток R. ruber ИЭГМ 346 в присутствии 50 мг/л диклофенака (1); 2 - биотический контроль 
Таблииа 5

Содержание суммарных липидов в клетках R. ruber ИЭГМ 346, выращенных в присутствии глюкозы (контроль) и диклофенака

\begin{tabular}{|l|c|c|}
\hline \multicolumn{1}{|c|}{ Вариант } & Сухая биомасса, г/л & $\begin{array}{c}\text { Суммарные липиды, \% } \\
\text { от сухого веса }\end{array}$ \\
\hline Контроль & $2,10 \pm 0,08$ & $43,40 \pm 1,72$ \\
\hline 50 мг/л диклофренак & $0,40 \pm 0,02$ & $70,80 \pm 4,46$ \\
\hline
\end{tabular}

Примечание. Родококки выращивали в течение 15 сут
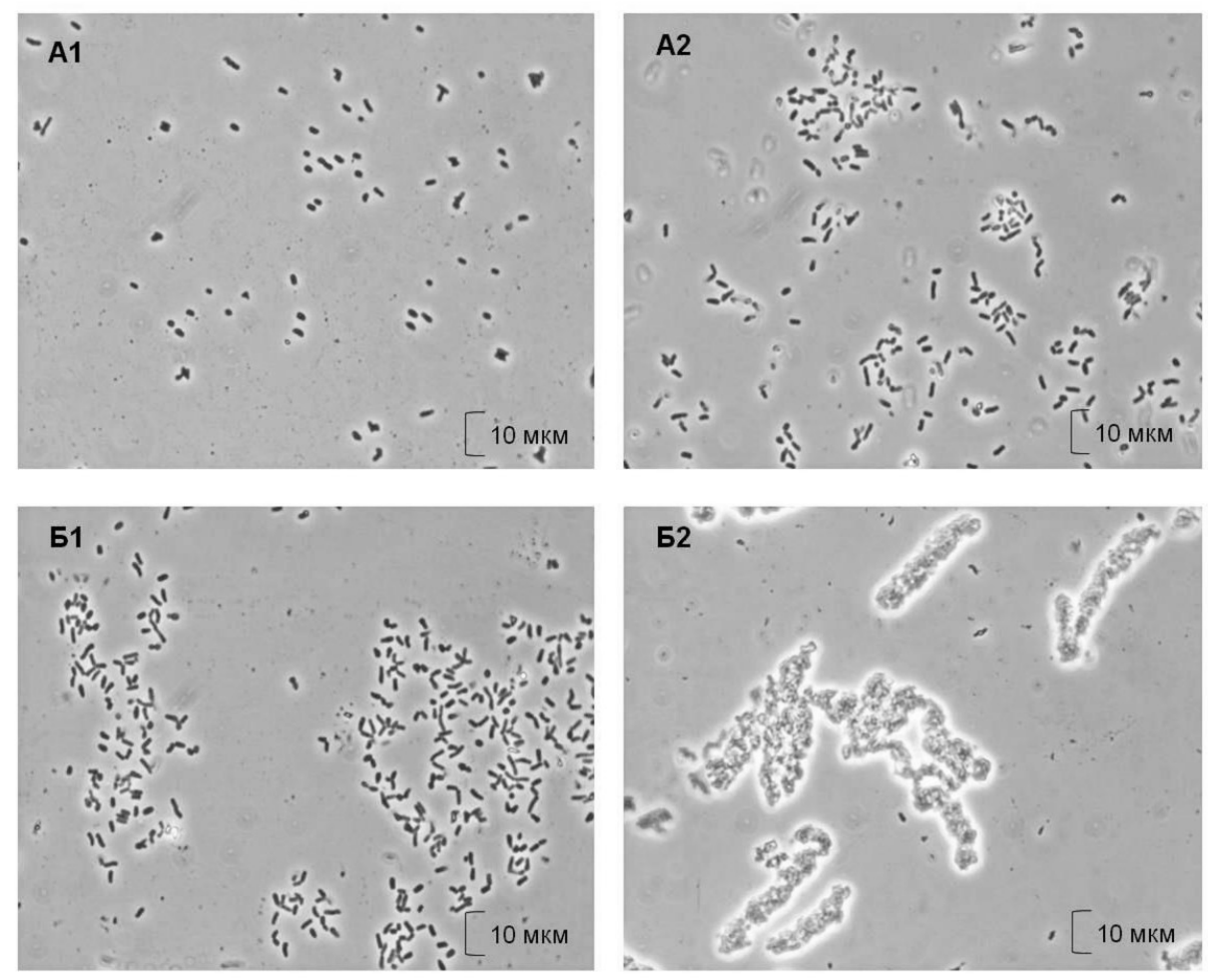

Puc. 9. Микрофотографии клеток R. ruber ИЭГМ 346. А-клетки, выращуенные в течение 15 сут в присутствии глюкозы; Б - в присутствии 50 мг/л диклофенака и глюкозы:

1 - без добавления $\left(\mathrm{NH}_{4}\right)_{2} \mathrm{SO}_{4} ; 2$ - в присутствии 0,6 $\mathrm{M}\left(\mathrm{NH}_{4}\right)_{2} \mathrm{SO}_{4} \times 1000$

структура развивающейся популяции пластично изменяется в сторону более устойчивых особей. Выявленные особенности рассматриваются нами в качестве механизмов адаптации родококков и, как следствие, повышения их устойчивости к токсическому воздействию фармполлютантов.

\section{Пути биодеструкции НПВС}

По нашим данным, процесс разложения диклофенака натрия (соединение 1) идет с образованием первичных гидроксипроизводных (соединения 4, 5) и последующей их метаболизации по трем путям (рис. 10). Следует отметить, что из 16 выявленных нами метаболитов только 4 (4'-гидроксидиклофенак, 5-гид- роксидиклофенак и два соединения бензохинониминовой структуры) аналогичны таковым, обнаруженным ранее другими исследователями у протеобактерий и Actinoplanes [15]. При этом во всех ранее обнаруженных метаболитах сохранялась связь C-N при втором атоме углерода в нехлорированном ароматическом кольце диклофенака. В данной публикации [15] отсутствовали сведения, подтверждающие факт раскрытия ароматического цикла в структуре образующихся соединений. В результате проведенных нами исследований впервые выявлены разрыв связи C-N в структуре диклофенака с образованием фенилуксусной кислоты и последующее раскрытие 


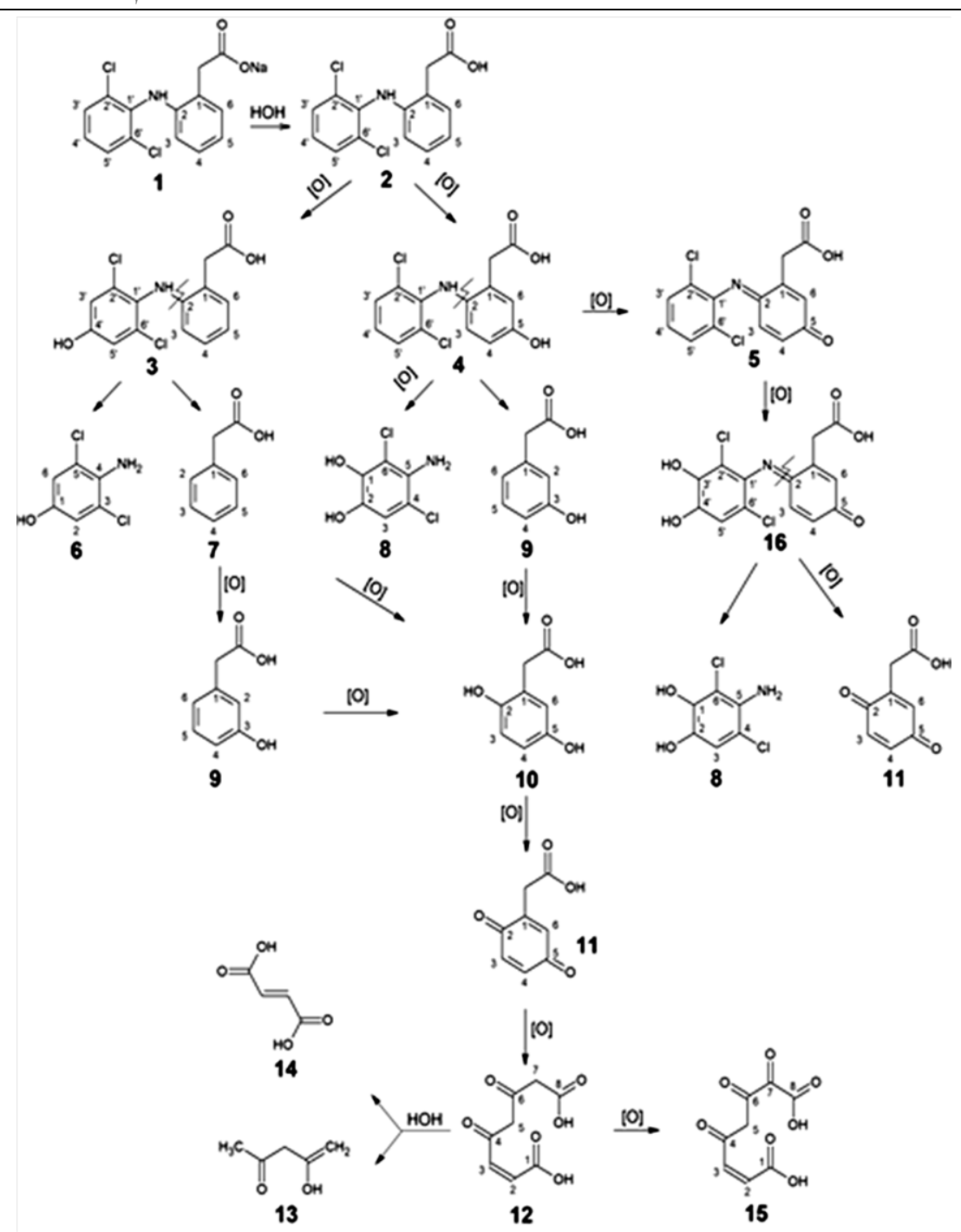

Рис. 10. Пути биодеструкиии диклофенака клетками R. ruber ИЭГМ 346. 1 - натриевая соль 2-(2-[2',6'дихлорфенил]-амино)-фенилуксусной кислоты, 2 -2-(2-[2',6'-дихлорфенил]-амино)-фенилуксусная кислота; 3 - 2-(2-[2',6'-дихлорфенил-4'-гидрокси]-амино)-фенилуксусная кислота; 4 - 2-(2-[2',6'дихлорфенил-5-гидрокси]-амино)-фенилуксусная кислота; 5 - 2-(1-(5-оксо-ииклогекса-1,3-диенил-2(2',6'-дихлор-фенилимино)-уксусная кислота; 6-4-амино-3,5-дихлорфенол; 7 - фенилуксусная кислота; $\boldsymbol{8}$ - 5-амино-4,6-дихлорбензол-1,2-диол; 9 - 3-гидроксифенилуксусная кислота; 10 - 2,5-дигидроксифенилуксусная кислота (гомогентизиновая кислота; 11 -2-(р-бензохинон-2)-уксусная кислота; 12 - 4,6-диоксо-окт-2-транс-ендиовая кислота (фумарилацетоуксусная кислота);

13 - 3-оксобутановая кислота (ацетоуксусная кислота); 14 - транс-бутендиовая кислота (фумаровая кислота); 15 - 4,6,7-триоксоокт-2-ендиовая кислота; 16 - 2-[1-(5-оксоииклогекса-1,3-диенил-2-(3',4'дигидрокси-2',6'-дихлорфенил)-имино]-уксусная кислота

хинонового цикла с образованием фумарилацетоуксусной кислоты (соединение 12) и простых продуктов её гидролиза - ацетоуксусной и фумаровой кислот (соединения 13, 14), что свидетельствует о полной детоксикации диклофенака [22]. О полной детоксикации полициклического хлорированного азотсодержащего фармполлютанта диклофенака свидетельствуют также выявленные реакции дегалогенирования соединений 6 и 8 с высвобождением свободных хлоридов. Как видно из рис. 11, выраженное увеличение содержания хлорид-ионов в среде наблюдалось в первые 20 сут эксперимента (от 0 до 18,7 мМ/л). Наиболее высокие $(25,4$ мМ/л) показатели содержания хлорид-ионов регистрировали на 40 -е сут эксперимента при последующем резком падении значений до $12,5 \mathrm{MM} / л$ к 50-м сут эксперимента. Высвобождение хлорид-ионов, по-видимому, 


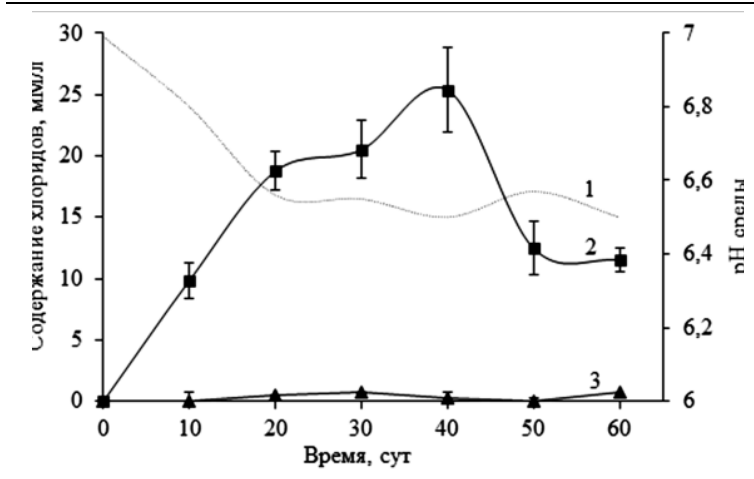

Рис. 11. Изменение содержания хлоридов в среде в прочессе биодеструкции 50 мг/л диклофенака клетками R. ruber ИЭГМ 346 (2). 1 - рН среды;

3 - контроль абиотической деструкиии

сопровождалось образованием $\mathrm{HCl}$, о чем свидетельствовало снижение показателя pH среды (с 6,9 до 6,5).

Токсичность продуктов биодеструкции диклофенака в отношении овса Avena sativa L. не выявлена (табл. 6). Расчетный фитоэффект, оказываемый продуктами биодеструкции диклофенака, составлял лишь $0,7 \%$, в то время как в присутствии диклофенака в концентрациях от 5 до 500 мг/л наблюдали подавление развития корневой системы овса от 23,1 до $100 \%$, что свидетельствовало о выраженном токсичном действии диклофенака в отношении тест-растения овса Avena sativa L.

По данным анализа, проведенного с использованием программы ECOSAR, показатели острой и хронической токсичности конечных продуктов биодеструкции диклофенака (фумарилацетоуксусной, ацетоуксусной, фумаровой кислот) составляли более 100 и 1000 мг/л соответственно. Согласно Глобальной гармонизированной системе классификации и маркировки химических веществ [26], это свидетельствовало о нетоксичности данных метаболитов для водных организмов (табл. 7).

По результатам проведенного PASSанализа, бензохинонимин (см. рис. 10, соединение 5) является субстратом СYР2J, GST A (коэффициент вероятности более $0,9)$ и обладает широкими ингибирующими свойствами (коэффициент вероятности более 0,8), может проявлять достаточно высокую антисеборейную активность и использоваться в лечении ринита, а также фобических расстройств (коэффициент вероятности более 0,7 ) (табл. 8). Полученные результаты указывают на перспективность дальнейшего углубленного исследования биологической активности этого перспективного метаболита диклофенака.

По нашим данным, метаболизация ибупрофена сопровождалась гидроксилированием молекулы экотоксиканта (соединение 1) с образованием 2-гидроксиибупрофена (соединение 2), 2,5-дигидроксиибупрофена (соединение 3) и 5-гидроксиибупрофена (соединение 5) и их последующим декарбоксилированием (рис. 12). Выявление дальнейших преобразований гидроксилированных и карбоксилированных метаболитов, образующихся в процессе биодеструкции ибупрофена, требует проведения более детальных исследований.

\section{Заключение}

В результате проведенных исследований впервые показана способность актинобактерий рода Rhodococcus к деструкции диклофенака натрия и ибупрофена. По данным масштабного (220 штаммов) скрининга актинобактерий из Региональ

Таблица 6

Фитоэффект, оказываемый диклофенаком и продуктами его биодеструкции

\begin{tabular}{|c|c|c|c|}
\hline Вариант & Длина корня, см & Фитоэфффект, \% & Тест-реакция \\
\hline Контроль (вода) & $11,00 \pm 1,14$ & 0,00 & \multirow{2}{*}{ Норма } \\
\hline Контроль среды & $11,40 \pm 0,87$ & $-3,20$ & \\
\hline $500 \mathrm{mг/л} \mathrm{ДН}$ & 0,00 & 100 & \multirow{4}{*}{ Эфффект торможения } \\
\hline 50 мг/л ДН & $0,20 \pm 0,10$ & 98,20 & \\
\hline 25 мг/л ДН & $6,50 \pm 1,08$ & 40,90 & \\
\hline $5 \mathrm{mг} / л \mathrm{gH}$ & $8,50 \pm 1,41$ & 23,10 & \\
\hline Продукты биодеструкции & $10,90 \pm 0,55$ & 0,70 & \multirow{2}{*}{ Норма } \\
\hline Биотический контроль & $9,00 \pm 1,05$ & 18,50 & \\
\hline
\end{tabular}


Расчет экотоксичности диклофенака и продуктов его биодеструкции с использованием программы ECOSAR

\begin{tabular}{|c|c|c|c|c|c|c|c|c|}
\hline \multirow{3}{*}{ 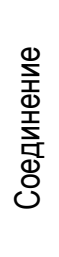 } & \multirow[b]{3}{*}{ ECOSAR класс } & \multicolumn{6}{|c|}{ Концентрация, мг/л } & \multirow[b]{3}{*}{$\begin{array}{l}\text { Категория } \\
\text { опасности }\end{array}$} \\
\hline & & \multicolumn{3}{|c|}{ Острая токсичность } & \multicolumn{3}{|c|}{ Хроническая токсичность } & \\
\hline & & $\begin{array}{c}\text { Рыбы } \\
\text { ЛД50 } \\
\text { (96 4) }\end{array}$ & $\begin{array}{c}\text { Дасрнии } \\
\text { ЛД }{ }_{50} \\
(48 \text { ч) }\end{array}$ & $\begin{array}{c}\text { Зеленые } \\
\text { водоросли } \\
\text { ЭД }_{50} \\
(96 \text { ч) }\end{array}$ & $\begin{array}{c}\text { Рыбы } \\
\text { ЭД } \text { म50 } \text { (30 сут) }\end{array}$ & $\begin{array}{c}\text { Дафннии } \\
\text { ЭД } \\
\text { (21 сут) }\end{array}$ & $\begin{array}{c}\text { Зеленые } \\
\text { водоросли } \\
\text { ЭД } \\
\text { (16 сут) }\end{array}$ & \\
\hline 1,2 & $\begin{array}{l}\text { Neutral Organics- } \\
\text { acid }\end{array}$ & 37,66 & 25,75 & 41,41 & 4,58 & 4,22 & 16,42 & $\|$ \\
\hline 3 & Phenols-acid & 68,21 & 34,80 & 142,67 & 8,19 & 6,61 & 66,03 & III \\
\hline 4 & Phenols-acid & 68,21 & 34,80 & 142,67 & 8,19 & 6,61 & 66,03 & III \\
\hline 5 & $\begin{array}{l}\text { Schiff Bases- } \\
\text { Azomethine-acid }\end{array}$ & 7,58 & 10,04 & 8,35 & 0,23 & 0,68 & 4,00 & $\|$ \\
\hline 6 & Phenol Amines & 10,50 & 1,09 & 4,12 & 0,60 & 0,36 & 0,76 & II \\
\hline 7 & $\begin{array}{l}\text { Neutral Organics- } \\
\text { acid }\end{array}$ & 3647,34 & 1964,52 & 1176,48 & 334,10 & 165,41 & 273,93 & IV \\
\hline 8 & Phenols, Poly & 38,06 & 434,37 & 8,49 & 24,19 & 172,05 & 0,99 & III \\
\hline 9 & Phenols-acid & 1665,51 & 313,93 & 1599,25 & 144,13 & 59,82 & 761,38 & IV \\
\hline 10 & $\begin{array}{l}\text { Hydroquinones - } \\
\text { acid }\end{array}$ & 3,17 & 4,91 & 7,12 & 0,28 & 5,72 & 13,95 & II \\
\hline 11 & Quinones-acid & 1,60 & 13,41 & 0,76 & 0,16 & 97,47 & 0,17 & II \\
\hline 12 & Diketones-acid & 3576,90 & 2165,74 & 367,57 & 3774,68 & 2930,32 & 1839,61 & IV \\
\hline 13 & $\begin{array}{l}\text { Neutral Organics- } \\
\text { acid }\end{array}$ & 399876,37 & 172315,18 & 41032,34 & 28162,12 & 7792,56 & 5821,70 & IV \\
\hline 14 & $\begin{array}{l}\text { Neutral Organics- } \\
\text { acid }\end{array}$ & 53316,05 & 25294,80 & 8964,33 & 4216,20 & 1496,17 & 1573,47 & IV \\
\hline 15 & $\begin{array}{l}\text { Vinyl/Allyl Ketones- } \\
\text { acid }\end{array}$ & 78982,13 & 47149,87 & 34104,79 & 977981,33 & 11420,81 & 35237,52 & IV \\
\hline 16 & $\begin{array}{l}\text { Phenols, Poly - } \\
\text { acid }\end{array}$ & 99,81 & 655,87 & 50,78 & 51,36 & 238,82 & 7,25 & III \\
\hline
\end{tabular}

Примечание. ЛД 50 - средняя летальная доза, ЭД 50 - средняя эффективная доза. I - высокотоксичные, II - токсичные, III - опасные для водных организмов, IV - нетоксичные [26].

Таблица 8

Расчет прогнозируемой биологической активности бензохинонимина (соединение 5) с использованием программы PASS Online

\begin{tabular}{|c|c|c|}
\hline$P_{a}$ & $P_{i}$ & Предполагаемая активность \\
\hline 0,929 & 0,003 & Субстрат СҮP2J2 \\
\hline 0,925 & 0,003 & Субстрат CҮP2J \\
\hline 0,887 & 0,006 & Ингибитор хлордекон редуктазы \\
\hline 0,837 & 0,009 & Ингибитор глюконат 2-дегидрогеназы \\
\hline 0,807 & 0,011 & Ингибитор экспрессии HIF1A \\
\hline 0,797 & 0,012 & Антагонист рецепторов анафилатоксина \\
\hline 0,758 & 0,021 & Ингибитор гликозилфосфратидилинозитол фосфролипазы \\
\hline 0,757 & 0,008 & Ингибитор линолеатдиол синтетазы \\
\hline 0,744 & 0,017 & Субстрат GST A \\
\hline 0,744 & 0,053 & Ингибитор цитохром-с редуктазы \\
\hline 0,728 & 0,023 & Ингибитор НАДФН-пероксидазы \\
\hline 0,728 & 0,064 & Лечение фобических расстройств \\
\hline 0,719 & 0,003 & Лечение ринита \\
\hline 0,707 & 0,036 & Антисеборейное действие \\
\hline 0,703 & 0,054 & Агонист целостности мембран \\
\hline
\end{tabular}




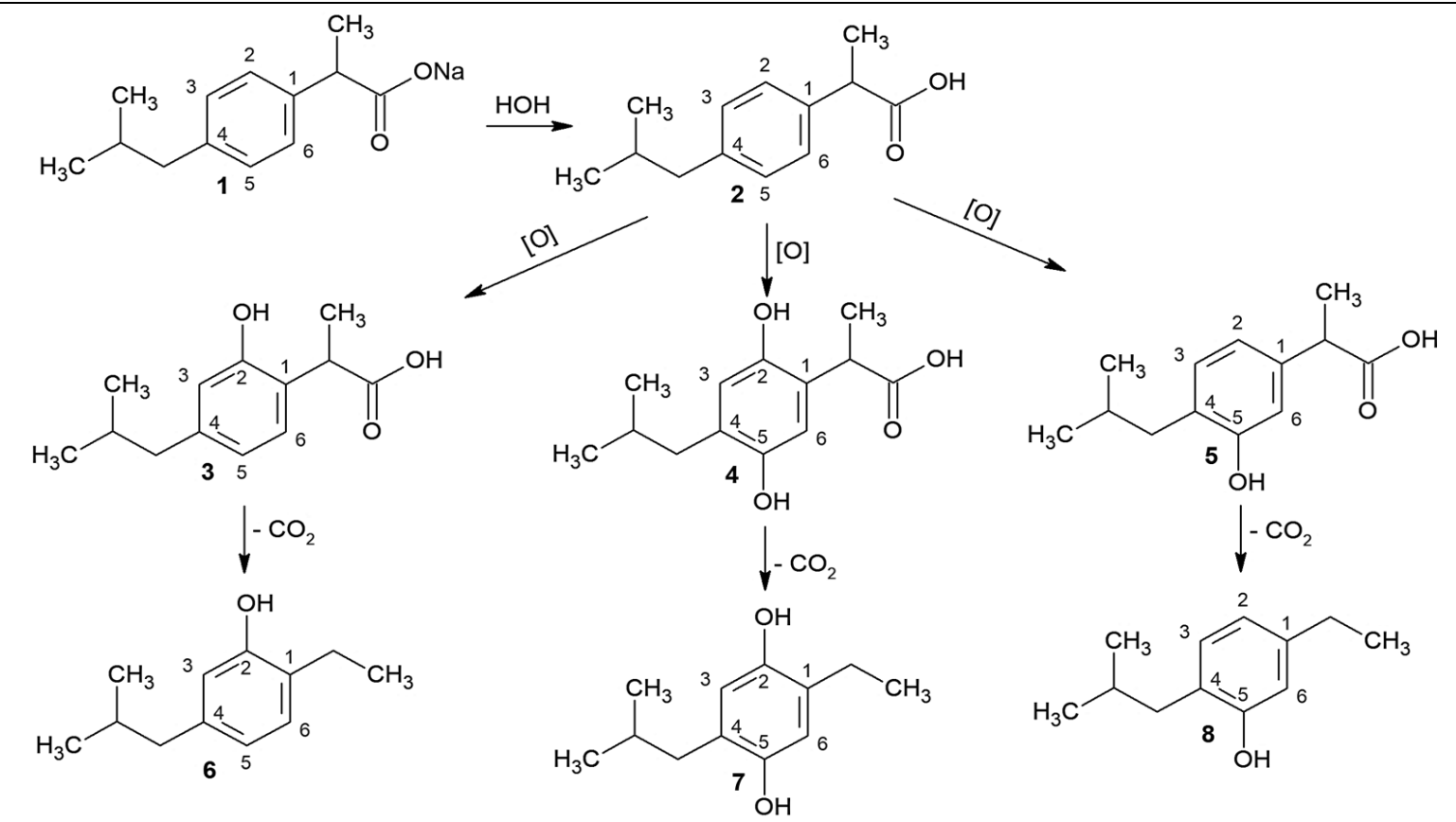

Pис. 12. Предполагаемая схема биодеструкиии ибупрофена клетками R. cercidiphylli ИЭГМ 1184. 1 - натриевая соль (RS)-2-(4-(2-метилпропил)фенил)пропановой кислоть;; 2 - (RS)-2-(4-(2-метилпропил)фенил)пропановая кислота;

3 - (RS)-2-(4-(2-гидрокси-2-метилпропил)фенил)пропановая кислота; 4 - (RS)-2-(4-(2,5-дигидрокси-2-метилпропил)фенил)пропановая кислота; 5 - (RS)-2-(4-(5-гидрокси-2-метилпропил)фенил)пропановая кислота; 6 - декарбоксилированное производное (RS)-2-(4-(2-гидрокси-2-метилпропил)фенил)пропановой кислоты; 7 - декарбоксилированное производное (RS)-2-(4-(2,5-дигидрокси-2метилпропил)фенил)пропановой кислоть; ; 8 - декарбоксилированное производное $R S)$-2-(4-(5-гидрокси-2-метилпропил)фенил)пропановой кислоть

ной профилированной коллекции алканотрофных микроорганизмов отобраны штаммы R.ruber ИЭГМ 346 и $R$. cercidiphylli ИЭГМ 1184, способные к полной биодеструкции диклофенака (50 мкг/л) и ибупрофена (100 мг/л) в течение 6 сут

Наиболее типичными реакциями родококков на воздействие НПВС являются формирование многоклеточных конгломератов, повышение содержания суммарных клеточных липидов и степени гидрофобности клеточной стенки, изменение морфометрических параметров, а также дзета-потенциала клеточной поверхности родококков. Полученные данные рассматриваются в качестве механизмов адаптации родококков и, как следствие, повышения их устойчивости к токсическому воздействию фармполлютантов. Показано, что процесс биодеструкции диклофенака катализируется цитоплазматическими и мембранносвязанными ферментами. В процессе на- чального окисления молекулы диклофенака участвуют цитохром Р450-зависимые монооксигеназы. Идентифицированы продукты бактериального разложения экотоксикантов и описаны пути их метаболизации. Впервые получены сведения, подтверждающие разрыв связи $\mathrm{C}-\mathrm{N}$ и раскрытие ароматического кольца в молекуле диклофенака с образованием неопасных метаболитов - фумарилацетоуксусной, ацетоуксусной, фумаровой кислот. Биоконверсия ибупрофена сопровождается гидроксилированием его молекулы с последующим карбоксилированием окисленных производных.

Полученные фундаментальные данные дают представление об экологической роли актинобактерий рода Rhodococcus в детоксикации фармполлютантов и создают предпосылки для реализации технических решений процессов доочистки сточных вод фармацевтических предприятий и обезвреживания опасных фармотходов. 


\section{Библиографический список}

1. de Carvalho C.C.C.R. Adaptation of Rhodococcus to organic solvents. In: Biology of Rhodococcus / Ed. H.M. Alvarez. - Cham: Springer, 2019. - P. 103-135.

2. Ivshina I.B., Kuyukina M.S., Krivoruchko A.V. Hydrocarbon-oxidizing bacteria and their potential in ecobiotechnology and bioremediation. In: Microbial Resources: From Functional Existence in Nature to Industrial Applications / Ed. I. Kurtböke. - London: Elsevier, 2017. - P. 121-148.

3. Maia A.S., Tiritan M.E., Castro P.M.L. Enantioselective degradation of ofloxacin and levofloxacin by the bacterial strains Labrys portucalensis F11 and Rhodococcus sp. FP1 // Ecotoxicology and Environmental Safety. - 2018. - Vol. 155. - P. 144-151.

4. Thelusmond J.R., Strathmann T.J., Cupples A.M. Carbamazepine, triclocarban and triclosan biodegradation and the phylotypes and functional genes associated with xenobiotic degradation in four agricultural soils // Science of the Total Environment. - 2019. - Vol. 657. - P. 1138-1149.

5. Ivshina I.B., Mukhutdinova A.N., Tyumina H.A., Vikhareva H.V., Suzina N.E., El'-Registan G.I., Mulyukin A.L. Drotaverine hydrochloride degradation using cyst-like dormant cells of Rhodococcus ruber // Current Microbiology. - 2015. - Vol. 70(3). - P. 307-314.

6. aus der Beek T., Weber F.A., Bergmann A., Hickmann S., Ebert I., Hein A., Küster A. Pharmaceuticals in the environment - Global occurrences and perspectives // Environmental Toxicology and Chemistry. 2016. - Vol. 35(4). - P. 823-835.

7. Acuña V., Ginebreda A., Mor J.R., Petrovic M., Sabater S., Sumpter J., Barceló D. Balancing the health benefits and environmental risks of pharmaceuticals: Diclofenac as an example // Environment International. - 2015. - Vol. 85. - P. 327-333.

8. Ding T., Yang M., Zhang J., Yang B., Lin K., Li J., Gan J. Toxicity, degradation and metabolic fate of ibuprofen on freshwater diatom Navicula sp. // Journal of Hazardous Materials. - 2017. - Vol. 330. - P. 127-134.

9. Alygizakis N.A., Gago-Ferrero P., Borova V.L., Pavlidou A., Hatzianestis I., Thomaidis N.S. Occurrence and spatial distribution of 158 pharmaceuticals, drugs of abuse and related metabolites in offshore seawater // Science of the Total Environment. - 2016. - Vol. 541. - P. 1097-1105.

10. Rivera-Jaimes J.A., Postigo C., Melgoza-Alemán R.M., Aceña J., Barceló D., López de Alda M. Study of pharmaceuticals in surface and wastewater from Cuernavaca, Morelos, Mexico: Occurrence and environmental risk assessment // Science of the Total Environment. - 2018. - Vol. 613-614. - P. 1263-1274.

11. Simazaki D., Kubota R., Suzuki T., Akiba M., Nishimura T., Kunikane S. Occurrence of selected pharmaceuticals at drinking water purification plants in Japan and implications for human health // Water Research. - 2015. - Vol. 76. - P. 187-200.

12. Oaks J.L., Gilbert M., Virani M.Z., Watson R.T., Meteyer C.U., Rideout B.A., Shivaprasad H.L., Ahmed S., Chaudhry M.J.I., Arshad M., Mahmood S., Ali A., Khan A.A. Diclofenac residues as the cause of vulture population decline in Pakistan. // Nature. - 2004. - Vol. 427(6975). - P. 630-633.

13. Yokota H., Taguchi Y., Tanaka Y., Uchiyama M., Kondo M., Tsuruda Y., Suzuki T., Eguchi S. Chronic exposure to diclofenac induces delayed mandibular defects in medaka (Oryzias latipes) in a sex-dependent manner // Chemosphere. - 2018. - Vol. 210. - P. 139-146.

14. Schröder P., Helmreich B., Škrbić B., Carballa M., Papa M., Pastore C., Emre Z., Oehmen A., Langenhoff A., Molinos M., Dvarioniene J., Huber C., Tsagarakis K.P., Martinez-Lopez E., Pagano S.M., Vogelsang C., Mascolo G. Status of hormones and painkillers in wastewater effluents across several European states - considerations for the EU watch list concerning estradiols and diclofenac // Environmental Science and Pollution Research. - 2016. - Vol. 23(13). - P. 12835-12866.

15. Domaradzka D., Guzik U., Wojcieszyńska D. Biodegradation and biotransformation of polycyclic nonsteroidal anti-inflammatory drugs // Reviews in Environmental Science and Biotechnology. - 2015. Vol. 14(2). - P. 229-239.

16. Marchlewicz A., Guzik U., Wojcieszyńska D. Over-the-counter monocyclic non-steroidal anti-inflammatory drugs in environment - Sources, risks, biodegradation // Water, Air, and Soil Pollution. - 2015. Vol. 226(10). - P. 1-13.

17. Catalogue of Strains of Regional Specialized Collection of Alkanotrophic Microorganisms [Электронный pecypc]. - URL: http://www.iegmcol.ru/strains/index.html (дата обращения: 06.06.2019).

18. Методические рекомендации: Обоснование класса опасности отходов производства и потребления по фитотоксичности. - М.: Федеральный центр гигиены и эпидемиологии Роспотребнадзора, 2007. - 15 с.

19. Żur J., Piński A., Marchlewicz A., Hupert-Kocurek K., Wojcieszyńska D., Guzik U. Organic micropollutants paracetamol and ibuprofen - toxicity, biodegradation, and genetic background of their utilization by bacteria // Environmental Science and Pollution Research. - 2018. - Vol. 25(22). - P. 21498-21524.

20. Klenk J.M., Nebel B.A., Porter J.L., Kulig J.K., Hussain S.A., Richter S.M., Tavanti M., Turner N.J., Hayes M.A., Hauer B., Flitsch S.L. The self-sufficient P450 RhF expressed in a whole cell system selectively catalyses the 5-hydroxylation of diclofenac // Biotechnology Journal. - 2017. - Vol. 12(3). - P. 1-23. 
21. Селянинов А.А., Баранова А.А., Вихарева Е.В. Время завершения кинетически моделируемых биомеханических процессов // Российский журнал биомеханики. - 2016. - Т. 20, № 4. - С. 368-377.

22. Ivshina I.B., Tyumina E.A., Kuzmina M.V., Vikhareva E.V. Features of diclofenac biodegradation by Rhodococcus ruber IEGM 346 // Scientific Reports. - 2019. - Vol. 9(1). - P. 1-13.

23. Neumann G., Veeranagouda Y., Karegoudar T.B., Sahin Ö.; Mäusezahl I., Kabelitz N., Kappelmeyer U., Heipieper H.J. Cells of Pseudomonas putida and Enterobacter sp. adapt to toxic organic compounds by increasing their size // Extremophiles. - 2005. - Vol. 9(2). - P. 163-168.

24. Halder S., Yadav K.K., Sarkar R., Mukherjee S., Saha P., Haldar S., Karmakar S., Sen T. Alteration of Zeta potential and membrane permeability in bacteria: a study with cationic agents // SpringerPlus. - 2015. Vol. 4. - P. 1-14.

25. Gogoleva O.A., Nemtseva N.V., Bukharin O.V. Catalase activity of hydrocarbon-oxidizing bacteria // Applied Biochemistry and Microbiology. - 2012. - Vol. 48(6). - P. 552-556.

26. United Nations. Globally Harmonized System of Classification and Labelling of Chemicals (GHS) / New York and Geneva: United Nations, 2011. - 562 p.

\title{
MECHANISMS OF BACTERIAL CONVERSION AND DEGRADATION OF PHARMA POLLUTANTS FROM NONSTEROIDAL ANTI-INFLAMMATORY DRUGS
}

\author{
I.B. Ivshina ${ }^{1,2}$, E.A. Tyumina ${ }^{1,2}$, G.A. Bazhutin ${ }^{1,2}$, A.A. Selyaninov ${ }^{4}$, E.V. Vikhareva ${ }^{3}$, \\ ${ }^{I}$ Perm Federal Research Center UB RAS \\ ${ }^{2}$ Perm State National Research University \\ ${ }^{3}$ Perm State Pharmaceutical Academy \\ ${ }^{4}$ Perm National Research Polytechnic University
}

Recently, there has been a steady increase in fundamental interest in studying the degree of bioavailability and toxic effects of pharmaceutical pollutants on natural microorganisms, which play the role of a primary response system to the xenobiotic load in the environment. Employing the bioresources of the Regional Specialised Collection of Alkanotrophic Microorganisms (IEGM, Large-Scale Research Facilities number 73559, WDCM \# 768, http://www.iegmcol.ru), the ability of actinobacteria of the genus Rhodococcus to decompose complex aromatic compounds that constitute the non-steroidal anti-inflammatory drugs (NSAIDs) widely used for medical purposes was first established. Active biodegraders of diclofenac and ibuprofen, which dominate among NSAIDs detected in the natural environment and pose the greatest potential risk to hydrobiota and humans, were selected. The kinetics and main characteristics of the biodegradation process of the tested pharmaceutical pollutants were investigated depending on the physiological state and culture conditions of their biodegraders. Cytochrome P450-dependent monooxygenases were shown to participate in the initial oxidation of the pharma pollutants. The products of bacterial decomposition of the ecotoxicants were identified, the pathways of their biodegradation were characterized, and the mathematical models of the process of complete bacterial degradation of pharmaceutical pollutants in high concentrations were described. For the first time, evidence for the $\mathrm{C}-\mathrm{N}$ bond breaking and aromatic ring opening in the diclofenac structure accompanied by the formation of metabolites harmless to living organisms was obtained. Potential bioactivity of individual metabolites of diclofenac and ibuprofen was evaluated. The most typical reactions of rhodococci exposed to NSAIDs were as follows: changes in the zeta potential, morphometric parameters and degree of hydrophobicity of bacterial cells, an increased content of total cellular lipids, and the formation of bacterial associates. The obtained results are considered to be mechanisms of rhodococci adaptation and their increased resistance to toxic effects of the pharmaceutical pollutants tested. The obtained fundamental data elucidate the environmental role of rhodococci in detoxification of pharma pollutants and underpin the implementation of innovative technical solutions for advanced pharmaceutical sewage treatment and the pharmaceutical waste disposal.

Keywords: biodegradation, actinobacteria, Rhodococcus, pharma pollutants, NSAIDs, ibuprofen, diclofenac. 


\section{Сведения об авторах}

Ившина Ирина Борисовна, доктор биологических наук, профессор, академик РАН, заведующий лабораторией алканотрофных микроорганизмов, Институт экологии и генетики микроорганизмов УрО РАН - филиал Пермского федерального исследовательского центра УрО РАН (ИЭГМ УрО РАН), 614081, г. Пермь, ул. Голева, 13; профессор кафедры микробиологии и иммунологии, Пермский государственный национальный исследовательский университет (ПГНИУ), 614990, г. Пермь, ул. Букирева, 15; e-mail: ivshina@iegm.ru

Тюмина Елена Александровна, младший научный сотрудник, ПФИЦ УрО РАН; аспирант, ПГНИУ; e-mail: elenatyumina@mail.ru

Бажутин Григорий Андреевич, младший научный сотрудник, ПФИЦ УрО РАН; аспирант, ПГНИУ; e-mail: sniffedbybadger@gmail.com

Селянинов Александр Анатольевич, доктор технических наук, профессор кафедры вычислительной математики, механики и биомеханики, Пермский политехнический национальный исследовательский университет (ПНИПУ), 614990, г. Пермь, Комсомольский пр., 29; e-mail: prof.selyaninov@yandex.ru

Вихарева Елена Владимировна, доктор фармацевтических наук, профессор, заведующий кафедрой аналитической химии, Пермская государственная фармацевтическая академия (ПГФА), 614990, г. Пермь, ул. Полевая, 2; e-mail: vihareva@pfa.ru 